\title{
EDITORIAL
}

\section{IL-21 and Sjögren's syndrome}

\author{
R Hal Scofield ${ }^{* 1-3}$ \\ See related research by Kang et al., http://arthritis-research.com/content/13/5/R179
}

\begin{abstract}
Treatment of Sjögren's syndrome is almost entirely symptomatic. A lack of true understanding of the underlying immunological pathology of the disease prevents directed therapy. Interleukin-21 (IL-21) is elevated in the serum of patients with this disease and is expressed by the lymphocytes infiltrating the salivary glands. The known functions of IL-21 in facilitating differentiation, proliferation, and survival of both $B$ and T cells mesh well with the findings in Sjögren's syndrome. Demonstration of IL-21 as a fundamental aspect of the pathophysiology of Sjögren's syndrome could lead to the development of anti-IL-21 therapy for this disease.
\end{abstract}

To be perfectly frank, there is no proper therapy for Sjögren's syndrome. Of course, there are therapies to treat the symptoms, but none that treats the underlying patholophysiology. There may be an obvious underlying reason that we cannot target the immunological or biological cause of Sjögren's syndrome. Namely, we as a community (that is, the research and clinical community interested in the disease) do not really understand the (presumed) immunological events leading to, advancing, and perpetuating this disease. This predicament begs the question of the basic assumption of biomedical research, especially translational research in which a human condition is under study. That is, a fuller understanding of pathophysiological mechanisms will naturally lead to therapies based on that understanding.

In the previous issue of Arthritis Research \& Therapy, Kang and colleagues [1] studied interleukin-21 (IL-21) in Sjögren's syndrome. Will determining that this cytokine is involved in Sjögren's syndrome open new therapeutic opportunities? This has certainly occurred in other

\footnotetext{
*Correspondence: hal-scofield@omrf.ouhsc.edu

'Departments of Medicine and Pathology, University of Oklahoma Health Sciences Center, 1000 North Lincoln Blvd, Oklahoma City, OK 73104, USA

Full list of author information is available at the end of the article
}

illnesses within the domain of rheumatology, both in common and in uncommon illnesses. When I was an internal medicine resident, not that long ago, the duties of the rheumatology clinic consisted mostly of checking urine analysis results and complete blood counts to determine whether patients with rheumatoid arthritis could receive a gold shot that day. A lot has changed since then - mostly because research determined that tumor necrosis factor-alpha (TNF $\alpha)$ is involved in the pathogenesis of rheumatoid arthritis. This led to the development of specific anti-TNF therapies, which basically changed the nature and natural history of the disease [2]. Pascual and colleagues [3] discovered that IL-1 is overexpressed in children with systemic-onset juvenile idiopathic arthritis. This knowledge led to a clinical trial of anti-IL-1 therapy in this illness, which was largely unresponsive to other, undirected therapies [4]. Dissecting genetic risk factors has led to therapy. For example, autosomal dominant periodic fever syndromes were determined to be caused by mutations in the TNF $\alpha$ receptor, and anti-TNF therapy works well in this disease [5], which is now known as TNF receptor-associated periodic syndrome (TRAPS). Common population variants of the IL-23 gene are associated with psoriasis, a genetically complex disease [6]. These genetic data, in part, gave rise to a clinical trial of an anti-IL-23 monoclonal antibody, which was found to be effective, in psoriasis [7]. Development of anti-interferon therapy is being undertaken with systemic lupus erythematosus as the target illness.

The known functions of IL-21 fit well with the findings in patients with Sjögren's syndrome. The disease is characterized by lymphocytic infiltrates in the salivary and lacrimal glands that contain both $\mathrm{B}$ and $\mathrm{T}$ cells that in many patients demonstrate ectopic germinal center formation. Kang and colleagues found that the degree of lymphocytic infiltration was correlated with IL-21 levels. Proliferation of both naïve and memory $\mathrm{CD}^{+} \mathrm{T}$ cells as well as activation, proliferation, and survival of $\mathrm{CD} 4^{+}$ $\mathrm{T}$ cells are supported by IL-21. B cells and CD4 ${ }^{+} \mathrm{T}$ cells are prominent in Sjögren's infiltrates. Furthermore, Kang and colleagues found expression of IL- 21 in the infiltrating cells. There are, of course, high levels of autoantibodies in the form of concentrations (in milligram per 
deciliter) of anti-Ro (or SSA) and anti-La (or SSB), along with consequent hypergammaglobulinemia, especially IgG1. The data are clear that B cells are hyperactivated in patients with Sjögren's syndrome. IL-21 promotes the proliferation of $\mathrm{B}$ cells, resulting in differentiation into plasma cells, which produce immunoglobulin, especially IgG1.

IL-21 is involved in the differentiation of $\mathrm{T}$ helper 17 (Th17) cells in that IL-21 acts to facilitate IL-23-induced expansion of these cells. As noted above, an IL-23 monoclonal antibody is available clinically, but the involvement of Th17 cells in the pathogenesis of Sjögren's syndrome is unknown. If Th17 cells are, in fact, players in Sjögren's syndrome, then perhaps the available anti-IL-23 monoclonal antibodies would be beneficial in the disease. This, of course, remains to be determined.

Certainly, the findings reported by Kang and colleagues [1] as well as others in regard to IL-21 in Sjögren's syndrome [8] and other inflammatory rheumatic illnesses $[9,10]$ suggest that therapy directed at IL-21 may be useful in human autoimmune disease. These findings need to be confirmed and advanced but perhaps will underpin the development of therapy directed at the underlying pathophysiology of Sjögren's syndrome.

\section{Abbreviations}

IL, interleukin; Th17, T helper 17; TNF, tumor necrosis factor.

\section{Competing interests}

The author declares that he has no competing interests.

\section{Author details}

'Departments of Medicine and Pathology, University of Oklahoma Health Sciences Center, 1000 North Lincoln Blvd, Oklahoma City, OK 73104, USA. ${ }^{2}$ Arthritis and Clinical Immunology Research Program, Oklahoma Medical Research Foundation, 825 NE 13th Street, MS 53, Oklahoma City, OK 73104 USA. ${ }^{3}$ Medical Service, Oklahoma City VA Medical Center, 921 NE 13th Street, Oklahoma City, OK 73104, USA.
Published: 19 December 2011

\section{References}

1. Kang KY, Kim H-O, Kwok S-K, Ju JH, Park K-S, Sun D-I, Jhun YJ, Oh HJ, Park S-H, Kim H-Y: Impact of interleukin-21 in the pathogenesis of primary Sjögren's syndrome: increased serum levels of interleukin-21 and its expression in the labial salivary glands. Arthritis Res Ther 2011, 13:R179.

2. Feldmann M, Maini RN: Anti-TNF therapy, from rationale to standard of care: what lessons has it taught us? J Immunol 2010, 185:791-794.

3. Pascual V, Allantaz F, Arce E, Punaro M, Banchereau J: Role of interleukin-1 (IL-1) in the pathogenesis of systemic onset juvenile idiopathic arthritis and clinical response to IL-1 blockade. J Exp Med 2005, 201:1479-1486.

4. Quartier P, Allantaz F, Cimaz R, Pillet P, Messiaen C, Bardin C, Bossuyt X, Boutten A, Bienvenu J, Duquesne A, Richer O, Chaussabel D, Mogenet A, Banchereau J, Treluyer JM, Landais P, Pascual V: A multicentre, randomised, double-blind, placebo-controlled trial with the interleukin-1 receptor antagonist anakinra in patients with systemic-onset juvenile idiopathic arthritis (ANAJIS trial). Ann Rheum Dis 2011, 70:747-754.

5. Kastner DL, Aksentijevich I, Goldbach-Mansky R: Autoinflammatory disease reloaded: a clinical perspective. Cell 2010, 140:784-790.

6. Bowes J, Orozco G, Flynn E, Ho P, Brier R, Marzo-Ortega H, Coates L, McManus R, Ryan AW, Kane D, Korendowych E, McHugh N, FitzGerald O, Packham J, Morgan AW, Bruce IN, Barton A: Confirmation of TNIP1 and IL23A as susceptibility loci for psoriatic arthritis. Ann Rheum Dis 2011, 70:1641-1644.

7. Papp KA, Langley RG, Lebwohl M, Krueger GG, Szapary P, Yeilding N, Guzzo C, Hsu MC, Wang Y, Li S, Dooley LT, Reich K, PHOENIX 2 study investigators: Efficacy and safety of ustekinumab, a human interleukin-12/23 monoclonal antibody, in patients with psoriasis: 52-week results from a randomised, double-blind, placebo-controlled trial (PHOENIX 2). Lancet 2008, 371:1675-1584

8. Yuan SL, Jiang L, Zhang XL, Li SF, Duan HM, Wang XF: Serum IL-21 level in patients with primary Sjögren's syndrome and clinical significance of IL-21 [in Chinese]. Xi Bao Yu Fen Zi Mian Yi Xue Za Zhi 2007, 23:124-126.

9. Sawalha AH, Kaufman KM, Kelly JA, Adler AJ, Aberle T, Kilpatrick J, Wakeland EK, Li QZ, Wandstrat AE, Karp DR, James JA, Merrill JT, Lipsky P, Harley JB: Genetic association of interleukin-21 polymorphisms with systemic lupus erythematosus. Ann Rheum Dis 2008, 67:458-461.

10. Andersson AK, Feldmann M, Brennan FM: Neutralizing IL-21 and IL-15 inhibits proinflammatory cytokine production in rheumatoid arthritis. Scand J Immunol 2008, 68:103-111.

doi:10.1186/ar3518

Cite this article as: Scofield RH: IL-21 and Sjögren's syndrome. Arthritis Research \& Therapy 2011, 13:137. 